\title{
The millipede Pachyiulus krivolutskyi Golovatch, 1977, the easternmost species of the eastern Mediterranean genus Pachyiulus Berlese, 1883, endemic to the western Caucasus (Diplopoda: Julida: Julidae)
}

\author{
Аиплопода Pacbyiulus krivolutskyi Golovatch, 1977, самый \\ восточный виА восточно-средиземноморского рода \\ Pachyiulus Berlese, 1883, эндемик Западного Кавказа \\ (Diplopoda: Julida: Julidae)
}

\author{
Aleksandr P. Evsyukov \\ А.П. Евсюков
}

\begin{abstract}
«Classical lyceum № 1», Balakireva Street 32, Rostov-on-Don 344004, Russia; E-mail aevsukov@mail.ru «Классический лицей № 1», ул. Балакирева 32, Ростов-на-Дону 344004, Россия.
\end{abstract}

\begin{abstract}
KEY WORDS: Diplopoda, Julidae, Pachyiulus krivolutskyi, morphism, clinal variation, distribution, Caucasus.

КЛЮЧЕВЫЕ СЛОВА: Diplopoda, Julidae, Pachyiulus krivolutskyi, морфизм, клинальная изменчивость, распространение, Кавказ.
\end{abstract}

ABSTRACT. Pachyiulus krivolutskyi, the largest and perhaps the most picturesque millipede in the Caucasus endemic to its western part, is properly redescribed based on abundant new material. Three main colour morphs are distinguished, all illustrated and mapped. Clinal variation is revealed, as the morphs show evident geographical patterns replacing each other from north to south.

РЕЗЮМЕ. На основе большого нового материала переописан Pachyiulus krivolutskyi, самая крупная и, пожалуй, самая колоритная многоножка-диплопода на Кавказе, эндемик его западной части. Выделены три главные цветовые морфы, закартированы их ареалы. У вида выявлена клинальная изменчивость, поскольку географически морфы сменяют друг друга с севера на юг.

\section{Introduction}

At least in Europe and in the Caucasus, the eastern Mediterranean millipede genus Pachyiulus Berlese, 1883, contains the largest species which often reach up to $9 \mathrm{~cm}$ in length and $7 \mathrm{~mm}$ in diameter [Enghoff, 1987]. This genus comprises about 20 species [Frederiksen et al., 2012] ranging from Italy in the west, through the Balkans, Hungary, Romania and the Crimea, to the Near East, Anatolia and the Caucasus in the east. The species are characteristically uniform in gonopod structure, the main differences referring to body coloration [Attems, 1940].

Unlike the Crimea, which supports only the widespread, likely anthropochore species $P$. flavipes Koch,
1847 [Lignau, 1905, sub Julus flavipes unicolor; Attems, 1907, sub $P$. flavipes], the Caucasus harbours an endemic species, P. krivolutskyi Golovatch, 1977. This species was first described as Iulus foetidissimus $\mathrm{Mu}-$ ralewicz, 1907, but because of homonymy with Iulus foetidissimus Savi, 1819, it had to be renamed [Mauriès et al., 1997]. This species had repeatedly been referred to as Julus (Pachyiulus) flavipes (?) [Lignau, 1903], Pachyiulus flavipes continentalis [Lignau, 1911, 1915; Isaev, 1911], Julus foetidissimus [Muralewicz, 1911] or P. foetidissimus [Muralewicz, 1913; Lohmander, 1936; Lang, 1959; Kobakhidze, 1965; Striganova, 1969a, b; Striganova, Mazantseva, 1979; Lokšina, Golovatch, 1979; Talikadze, 1984] until Mauriès et al. [1997] validated Pachyiulus krivolutskyi as the proper replacement name. P. krivolutskyi was originally described from western Georgia and said to be distinguished from $P$. foetidissimus primarily by the lack of a colour pattern [Golovatch, 1977].

In the checklists by Lokšina, Golovatch [1979] and Talikadze [1984], both P. foetidissimus and P. krivolutskyi were regarded as independent species, while Lohmander [1936] recorded a 9 of $P$. flavipes from near Sukhum, Abkhazia, an apparent introduction.

From the very start, $P$. krivolutskyi ( $=P$. foetidissimus) was distinguished from all congeners by its remarkably repelling "garlic" odour [Muralewicz, 1907; Isaev, 1911; Lignau, 1903 etc.]. The stinking is so unbelievably strong that the presence of $P$. krivolutskyi it the field can be detected dozens of meters away from the site, usually a forest, where the animals actually 
occur. Apparently, this striking odour prompted $\mathrm{Mu}-$ ralewicz [1907] to name his species "foetidissimus", which in Latin means "the most stinking".

Among the Caucasian julid species, only Amblyiulus continentalis (Attems, 1903), from Hyrcania, possesses a similarly strong "garlic" odour [Golovatch, in litt.].

Another remarkable character is its usually very bright, yellow-and-black colour pattern which was first illustrated by Lignau [1903]. Occasionally, the pattern is absent, one of the reasons why Golovatch [1977] described P. krivolutskyi.

The present paper provides a review of this remarkable species which is the largest and perhaps the most picturesque millipede in the entire Caucasus, the easternmost congener endemic to the western part of the region.

\section{Material and methods}

All material has been shared between the collections of the Zoological Museum of the Moscow State University (ZMUM) and the private collection of the author (AE), both Russia. The specimens are stored in 70-75\% ethanol. All adult specimens were measured with regard to body length, body diameter, and the number of podous and apodous segments was recorded. A "body segment formula" indicates the number of podous (including the gonopod-bearing segment) and apodous segments in an individual. This formula is $x(-y)$ where $x=$ sum of podous and apodous body segments, excluding telson, $y$ $=$ number of apodous body segments before telson. Photographs were taken using a Lomo MSP microscope and a Sony A camera.

In the catalogue section, D stands for a description or descriptive notes, $\mathrm{R}$ for new records, while $\mathrm{M}$ for a mere mention.

\section{Results}

\section{Pachyiulus krivolutskyi Golovatch, 1977} Figs 1-27, Map.

Iulus foetidissimus Muralewicz, 1907: 342-344 (D).

Pachyiulus foetidissimus: Lohmander, 1936: 153-155(R); Lang, 1959: 1791 (M); Kobakhidze, 1965: 394-395 (R); Striganova, 1969a: 822 (R); 1969b: 1624 (R); Striganova, Mazantseva, 1979: 416 (R); Lokšina, Golovatch, 1979: 387 (M); Talikadze, 1984: 143 (R).

Julus (Pachiyulus) flavipes (?) [sic!]: Lignau, 1903:113-115 (R). Pachyiulus flavipes continentalis: Lignau, 1911: 45-54 (D, R); 1915: 379-380 (D, R); Isaev, 1911: 298 (R).

Pachyiulus krivolutskyi Golovatch, 1977: 46-48 (D).

Pachyiulus krivolutskyi: Lokšina, Golovatch, 1979: 387 (M); Talikadze, 1984: 143 (R); Mauriès et al., 1997: 282 (D); Chumachenko, 2012: 451 (R); 2016: 409 (R); Korobushkin et al., 2016: 25-26 (R).
MATERIAL. 2 ㅇ, 1 juv. (ZMUM 93445 ), RUSSIA, Adygea Republic, Caucasian Nature Reserve, Guzeripl, forest, 1967, leg. ?; 5 90 (ZMUM p3446), same locality and date, leg. ?; $4 \sigma^{7} \sigma^{7}$ (ZMUM

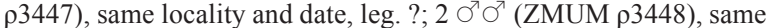
locality and date; $18 \sigma^{7} \sigma^{\top}, 16$ 우, 1 juv. (ZMUM 03449), Caucasian Nature Reserve, Pasture Abago near Guzeripl, Abies, Fagus, Acer, Betula etc. forest, up to timber line and in subalpine meadow, 1700$1800 \mathrm{~m}$ a.s.1., litter, under bark and stones, 24-26.V.1983, leg. S. Golovatch; 1 q (AE), Maikop, Quercus and Fagus forest, litter, 13.X.2007, leg. M. Shapovalov; 1 (AE), near Nikel, Belaya River valley, 25.VI.2007, leg. G. Chesnokov.

$1 \sigma^{7}$ (ZMUM 03207 ), RUSSIA, Krasnodar Prov., Severskaya Distr., Mt Derbiy ca $15 \mathrm{~km} \mathrm{SW}$ of Ubinskaya, $800-850 \mathrm{~m}$ a.s.1., old Quercus, Fagus, Fraxinus, Alnus etc. forest, litter, bark, 2.VII.1986; 1 ○, 2 oᄋ, 2 juv. (ZMUM 03208 ), same locality, 2-10 km S of Ubinskaya, Quercus, Fagus, Carpinus etc. forest, 300-450 m a.s.1., litter and under bark, 3-4.VII.1986; $3 \sigma^{\top} \sigma^{\top}, 1$ O , 2 juv. (ZMUM 03209 ), Mostovskoy Distr., Shedok N of Psebai, karst funnel, wet Fagus, Acer, Quercus etc. forest, litter and under bark, $650 \mathrm{~m}$ a.s.1., 4.VIII.1986; $2 \sigma^{7} \sigma^{\top}, 1$ juv. (ZMUM 13210 ), Goryachiy Klyuch, $10 \mathrm{~km} \mathrm{~S}$ of Fanagoriyskaya, near Cave Fanagoriyskaya, mixed forest (Fagus, Quercus, Picea etc.), litter, under stones and in rotten logs, 30.X.1981; 1 o', 3 우 (ZMUM $\rho 3211$ ), same locality, 12 km SW of Fanagoriyskaya, near Cave Fanagoriyskaya, Fagus, Acer etc. forest, litter, logs, 19.V.1983; 2 90 (ZMUM 03212), Caucasian Nature Reserve, Pslukh ca $20 \mathrm{~km} \mathrm{~S}$ of Krasnaya Polyana, Mt Kogot, Fagus and Abies forest up to timber-line, 1650-1850 m a.s.1., litter, under bark and stones, 20.V.1985; $2 \sigma^{\top} \sigma^{\top}, 1$, 1 juv. (ZMUM $\rho 3213$ ), Caucasian Nature Reserve, Krasnaya Polyana, 600-750 m a.s.1., Quercus, Fagus, Castanea, Carpinus etc. forest, litter, under bark and stones, 8-9.VIII.1986, all leg. S. Golovatch; $3 \sigma^{7} \sigma^{7}$ (ZMUM $\left.\rho 3440\right)$, Krasnaya Polyana, 68.VI.1978, leg. V. Dolin; 1 ' (ZMUM p3441), Khosta, Buxus grove, 24.VIII.1973, leg. V. Minoranskiy; 1 q (ZMUM $\rho 3442)$, same locality, Taxus and Buxus forest with Fagus, litter and

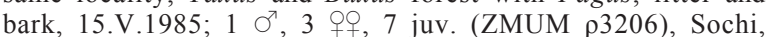
Lazarevskoye, Soloniki, deciduous forest, litter, 28.X.1981; 2 qo (ZMUM $\rho 3205$ ), Tuapse Distr., $15 \mathrm{~km} \mathrm{SE}$ of Novomikhailovskiy, Psebe, deciduous forest, litter, under stones and in rotten logs, 29.X.1981, all leg. S. Golovatch; 1 ㅇ (ZMUM 3443 ), env. Gelendjik, $2.5 \mathrm{~km}$ ENE of Aderbievka, E slope of Markotkh Range, forest, ca $400 \mathrm{~m}$ a.s.1., $44^{\circ} 36^{\prime} 26^{\prime \prime} \mathrm{N}$ 3804'29"E, 30.IV.2016, leg. K. Makarov \& O. Makarova.

1 , 1 juv. (ZMUM 93444$)$, RUSSIA, Karachaevo-Cherkessia, ca $30 \mathrm{~km} \mathrm{~S}$ of Kurdjinovo, $4 \mathrm{~km}$ N of Damkhurts, 1050-1100 m a.s.1., Laba River valley, Fagus, Acer, Picea etc. forest, litter, bark, 4.VIII.1986, leg. S. Golovatch.

$3 \sigma^{\top} \sigma^{7}, 1$ (ZMUM $\rho 3450$ ), ABKHAZIA, Sukhumi Distr., Bzyb Valley, Pskhu, 700-950 m a.s.1., Fagus, Quercus, Castanea etc. forest, litter, under bark and stones, 15-16.VIII.1986; 1 q (ZMUM 03451 ), Myussera Nature Reserve, 20-130 m a.s.1., mixed deciduous forest (Castanea, Alnus etc.), litter, under bark and stones, 8-10.IV.1983; 2 90 (ZMUM 03452), same locality and date, all leg. S. Golovatch; 2 ○ $\sigma^{\top}, 5$ 0 (ZMUM $\left.\rho 3453\right)$, Gulripsh Distr., Shaumyanovka, 9.V.1985, leg. A. Markosyan; $1 \sigma^{7}, 1$ \% (ZMUM 03454 ), Gumista Nature Reserve, Upper Tsumur, Fagus,

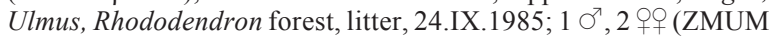
९3455), Djgerda, foothills of Kodor Mt. Range, litter, 21.IX.1985, all leg. I. Ushakov; 1 (ZMUM $\rho 3456)$, upper reaches of Galidzga River, VIII.1985, leg. E. Kvavadze.

$2 \sigma^{7} \sigma^{7}, 2$ (Z) (ZMUM 03457 ), GEORGIA, Tkibuli Distr., Mukhura ca 15 km E of Tkibuli, 700-800 m a.s.1., Castanea, Fagus, Carpinus etc. forest, litter, under bark and stones, 7-9.V.1987, leg.

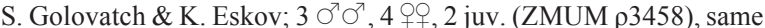

Figs 1-15. Colour morphs in Pachyiulus krivolutskyi Golovatch, 1977: 1-5 - $0^{7}$ from Adygea, morph A; 6-10 — $\bigcirc^{7}$ from Abkhazia, morph B; 11-15 - $\sigma^{7}$ from near Kutaisi, Georgia, morph C; 1, 6, 11 - anterior part body, dorsal views; 2, 7, 12 - same, lateral views; 3, 8,13 - midbody segments, lateral views; 4, 9, 14 - same, dorsal views; $5,10,15$ - caudal part of body, lateral views. Pictures taken not to scale.

Рис. 1-15. Цветовые морфы Pachyiulus krivolutskyi Golovatch, 1977: 1-5 - ○ из Адыгеи, морфа А; 6-10 — ○ из Абхазии, морфа B; 11-15 — О из окрестностей Кутаиси (Грузия), морфа C; 1, 6, 11 - передняя часть тела, сверху; 2, 7, 12 - то же, сбоку; 3, 8, 13 средняя часть тела, сбоку; 4, 9, 14 - то же, сверху; 5, 10, 15 - задняя часть тела, сбоку. Сфотографировано без масштаба. 


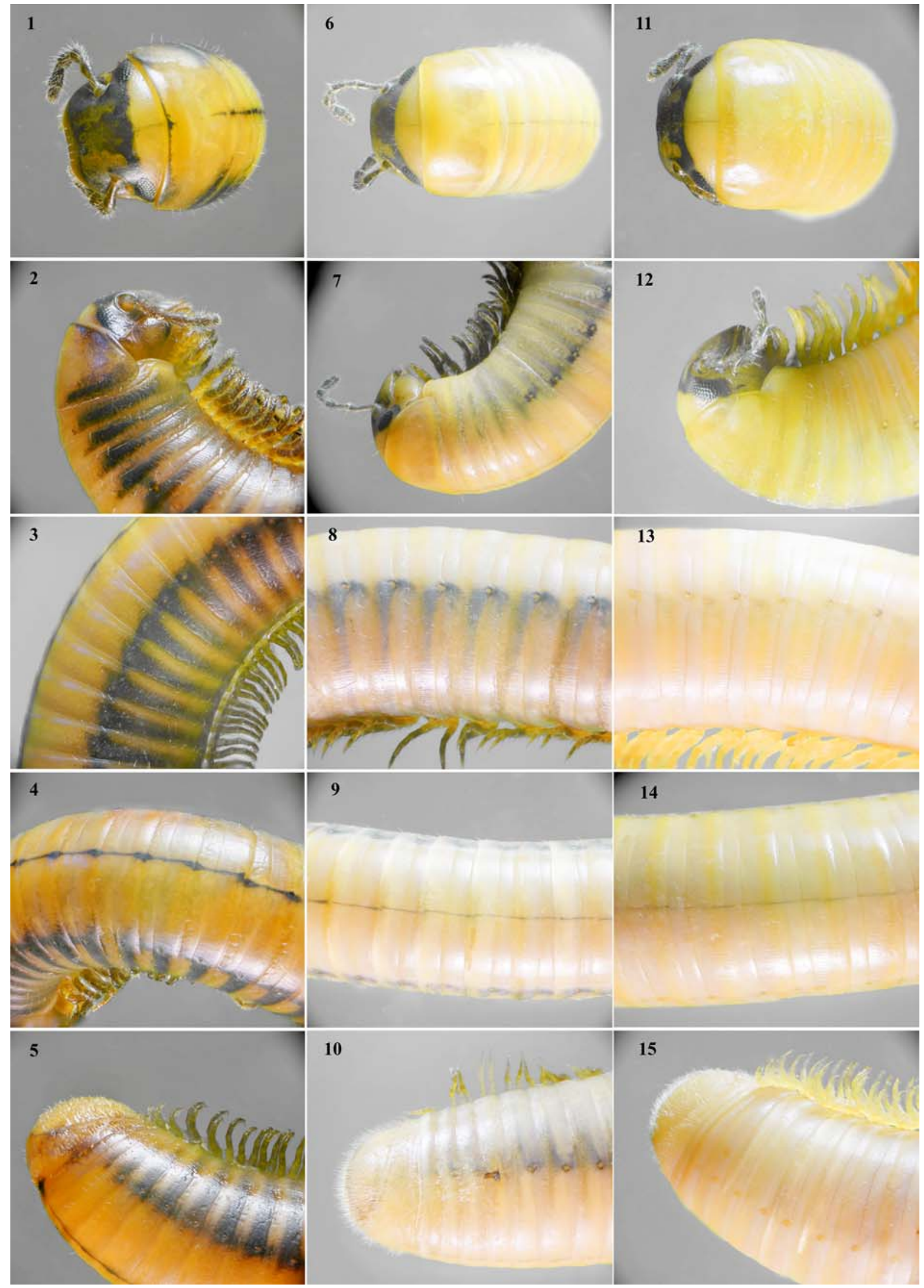


locality, $14 \mathrm{~km} \mathrm{E}$ of Tkibuli, Quercus and Fagus forest, litter and under stones along spring, 23.X.1981; 1 +, 1 juv. (ZMUM $\rho 3459$ ), Kutaisi Distr., Sataplia Nature Reserve, deciduous forest, litter and under stones, 25.X.1981, all leg. S. Golovatch; 1 9 (ZMUM $\rho 3460$ ), same locality, $400 \mathrm{~m}$ a.s.l., Fagus forest, 5.VI.1981, leg. S. Golovatch and J. Martens; 1 $\sigma^{7}, 3$ 우 (ZMUM $\rho 3461$ ), same locality, Fagus and Carpinus forest, litter, 15-17.IV.1988, leg. D. Logunov; $1 \mathrm{O}^{7}$ (ZMUM 03462$)$, Svanetia, Khaishura River valley near Khaishi, 2-3 km upstream off mouth, $600 \mathrm{~m}$ a.s.1., Quercus, Fagus etc. forest, 5.IX.1986, leg. A. Ryvkin; $2 \sigma^{7} \sigma^{7}, 1+2$ juv. (ZMUM ९3463), Svanetia, $40 \mathrm{~km} \mathrm{~W}$ of Mestia, Kherkhvashi E of Nakra (= Naki), 1250-1700 m a.s.1., Ouercus, Fagus, Carpinus, Picea, Abies etc. forest, litter and bark, 21.VIII-21.IX.1986; 1 \& (ZMUM $\rho 3464$ ), $45 \mathrm{~km} \mathrm{~W}$ of Mestia, above Nakra (= Naki), $1700 \mathrm{~m}$ a.s.l., Abies, Picea etc. forest, litter and under stones, 3.IX.1986; $1 \mathrm{O}^{7}$ (ZMUM ९3466), Svanetia, Mestia, $1500 \mathrm{~m}$ a.s.l., litter and under stones, 22.X.1979; 1 o', 1 juv. (ZMUM م3465), same locality, $1500 \mathrm{~m}$ a.s.l., Betula and Rhododendron on moraine, litter and under stones, 5, 16.IX.1986, all leg. S. Golovatch; 1 OT $^{\text {(ZMUM } \rho 3467), ~ s a m e ~}$ locality, Nenskra Valley, Lukhi $\mathrm{N}$ of Khaishi, litter, $800 \mathrm{~m}$ a.s.l., 2.IX.1986; 1 \& (ZMUM $\rho 3468$ ), same locality, Khumprer Valley, 1.5-2 km upstream off mouth, near Dizi, $1000 \mathrm{~m}$ a.s.l., forest, litter, 9.IX.1986, all leg. A. Ryvkin; 1 \& (ZMUM 03469$), 10 \mathrm{~km}$ N of Jvari, 800 m a.s.1., Buxus, Fagus, Picea, Taxus etc. forest, litter, 20 21.VIII.1986, leg. S. Golovatch; $20^{7} \sigma^{7}, 2$ 우, 1 juv. (ZMUM p3470), Megrelskiy (= Egrisskiy) Mt. Range, NW slope of Mt
Tsekhuri, 1500-1800 m a.s.1., Fagus forest, litter, 18-19.VIII.1988, leg. I. Belousov.

REDESCRIPTION. Length of adults $41-68 \mathrm{~mm}$, width 3.4-4.7 mm $\left(\mathrm{O}^{7}\right)$, or length 45-90, width 4.0-5.9 (+). Body segment formula (excluding telson) from $43(-2)$ to $59(-1)$ $\left(\mathrm{O}^{7}\right)$, or from $44(-2)$ or $65(-2)(+)$.

Body coloration of adults from entirely yellow to yellowand-black; a thin axial line, antennae, ocellaria, as well as entire clypeolabrum and vertex (but neither occiput nor usually a paramedian pair of lighter spots above ocellaria) black; legs yellow to blackish; lateral parts of body from entirely yellow to infuscate due to a narrow, continuous, black line on each side level to ozopores, as well as brown to blackish metazonae below ozopores (Figs 1-15).

$\sigma^{7}$. Eye patches rounded, suboval, in adults composed of 39-48 small ocelli. Epicranial setae 1+1, supralabral setae 59 , labral ones ca 40. Genae with small, lateral, rounded lamellae. Antennae short, rather slender and clavate, in situ reaching somite 2. Gnathochilarium with a group of long setae in distal part of stipes (ca 18); 6+1 setae on each lingual lamella. Length ratios of antennomeres $2-7$ as $4.5: 4.1: 3.7: 4.0: 2.3: 0.7$, width ratios as 2.0:2.1:1.9:2.2:1.7:1.0, respectively. Antennomeres 5 and 6 each with a complete distodorsal corolla of sensory bacilli (Fig. 17).

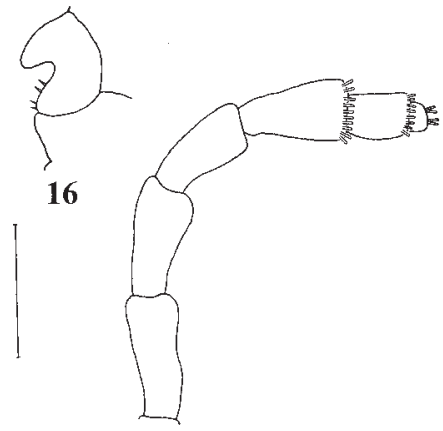

17
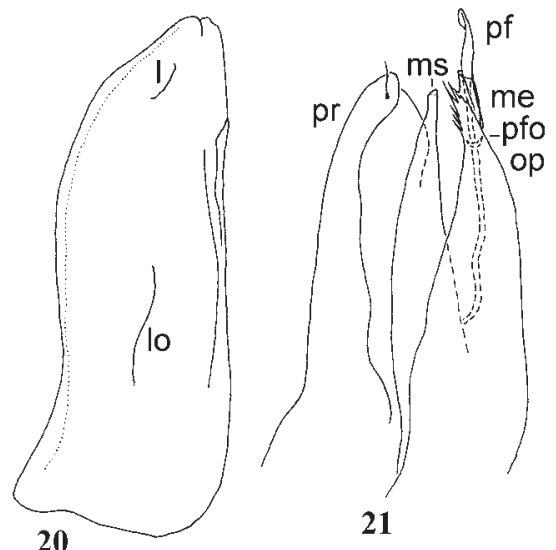

21

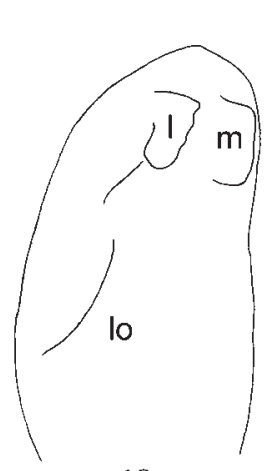

18

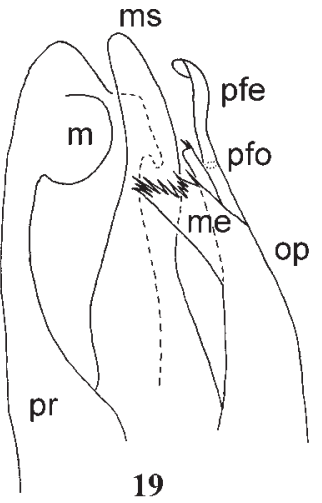

19

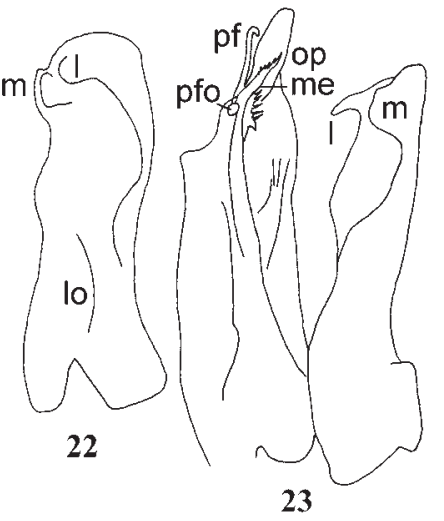

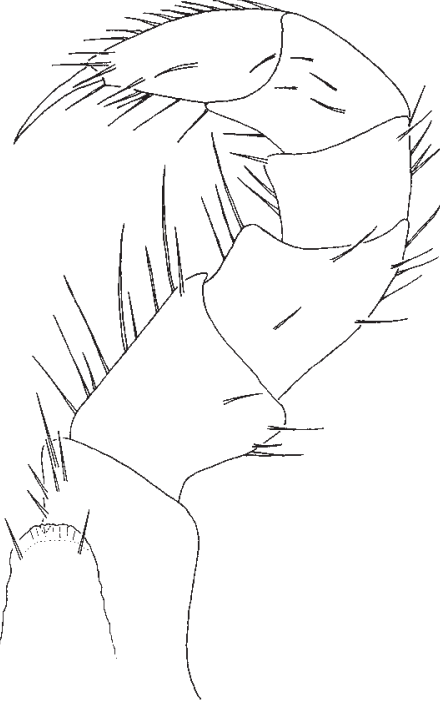

24

Figs 16-24. Pachyiulus krivolutskyi Golovatch, 1977: 16-19, 24 - $\sigma^{7}$ from Adygea, morph A; 20-21 — $\sigma^{7}$ from near Kutaisi, morph C; 22-23 - $\mathrm{O}^{7}$ from Abkhazia, morph A [after Lignau, 1915]; 16 - leg 1; 17 — antenna; 24 - left leg 2 and penes; 18, 20, 22 - promere; 19, 21, 23 - both gonopods; 16, 18, 20, 22, 24 - caudal view; 17 - lateral view; 19, 21, 23 - mesal view; Scale bar: 0.3 mm (16-21, $24)$, not to scale (22-23). Designations explained in text.

Рис. 16-24. Pachyiulus krivolutskyi Golovatch, 1977: 16-19, 24 - О7 из Адыгеи, морфа А; 20-21 — О7 из окрестностей Кутаиси (Грузия), морфа С; 22-23 - О७ из Абхазии, морфа A [по Lignau, 1915]; 16 - нога 1; 17 - антенна; 24 - левая нога 2 и пенисы; 18, 20, 22 - промер; 19, 21, 23 - оба гонопода; 16,18, 20, 22, 24 - сзади; 17 - сбоку; 19, 21, 23 — изнутри. Масштаб: 0,3 мм (16-21 и 24), без масштаба (22 и 23). Обозначения объяснены в тексте 
Body subcylindrical, slender. Segments 6 and 7 enlarged compared to others. Suture dividing pro- and metazona distinctly constricting both zonites. Ozopores large, lying behind, but not touching suture. Prozonae almost smooth. Metazonae very densely striate, even more densely ventrad, more sparsely dorsally; ca 60 striae per about $1 / 4$ of metazonital surface, i.e. between axial line and ozopore. A transverse row of sparse, thin, short setae at hind edge of metazonae, setae gradually growing denser and somewhat longer towards telson. Telson with very dense and short setae on epiproct and anal valves; without caudal projection of epiproct.

Legs relatively short. Anterior legs with broad soles on tibia and praefemur. Leg-pair 1 strongly reduced, unciform, with a group of short setae ventrally near base (Fig. 16). Legpair 2 unmodified; penes flat, rounded at apex (Fig. 24).

All three pieces of each gonopod half highly condensed (Figs 18-23). Promeres (pr) nearly as high as or, more usually, slightly shorter than opisthomeres (op), quite variable in shape, with one (more rarely) or two (usually) distal lobes or teeth (lateral $\mathbf{l}$ and mesal $\mathbf{m}$ ) and one rounded, proximal, membranous lobe (lo). Mesomere branch (ms) with an acuminate or rounded apex. Opisthomere (op) with a pseudofovea (pfo) and a pseudoflagellum (pf), the latter typically recurved at tip and bearing a thin, membranous, densely and deeply fringed lamella (me) mesally at base.

+ . Same as in $\sigma^{7}$, except supralabral setae being $5-7$, while segments 6 and 7 not enlarged compared to others. Vulvae not studied.

\section{Discussion}

Three colour morphs can be distinguished in $P$. krivolutskyi, as follows.
Morph A: antennae, genae, most of head (except for a light band in occipital region and a paramedian pair of marbled lighter spots above ocellaria), anterior legpairs, a thin, continuous, axial line, a continuous longitudinal stripe at ozopore level on each side, and transverse bands on metazonae below ozopores are all black to blackish (Figs 1-5). This form is especially common and widespread, as it inhabits the northern and central parts of the distribution range, including all records from the Republic of Adygea, the Krasnodar Province, the Republic of Karachaevo-Cherkessia, the Sukhum District of Abkhazia, and Svanetia (the Mestia District) in Georgia (Map, red circles).

Morph B: antennae, legs, most of head (except for a broad light band in occipital region and a paramedian pair of light spots above ocellaria), a discontinuous lateral stripe level to ozopores on each side, a thin axial line, and transverse bands on metazonae below ozopores are all grey or greyish (Figs 6-10). This colour morph appears to be transitional between morphs A and $\mathrm{C}$, also occupying a transitional area in Georgia and Abkhazia (Map, red-and-blue circles).

Morph C: only antennae, much of head, and a thin axial line are blackish to grey, the predominant colour being white to yellow (Figs 11-15). This colour morph inhabits the southern part of the distribution area, being restricted to the Kutaisi District of Georgia (blue circles in Map).

The distribution of the colour morphs of P. krivolutskyi shows what seems to be clinal variation. The northern and central parts of the distribution range are inhabited by morph A. Morph B occurs only south of

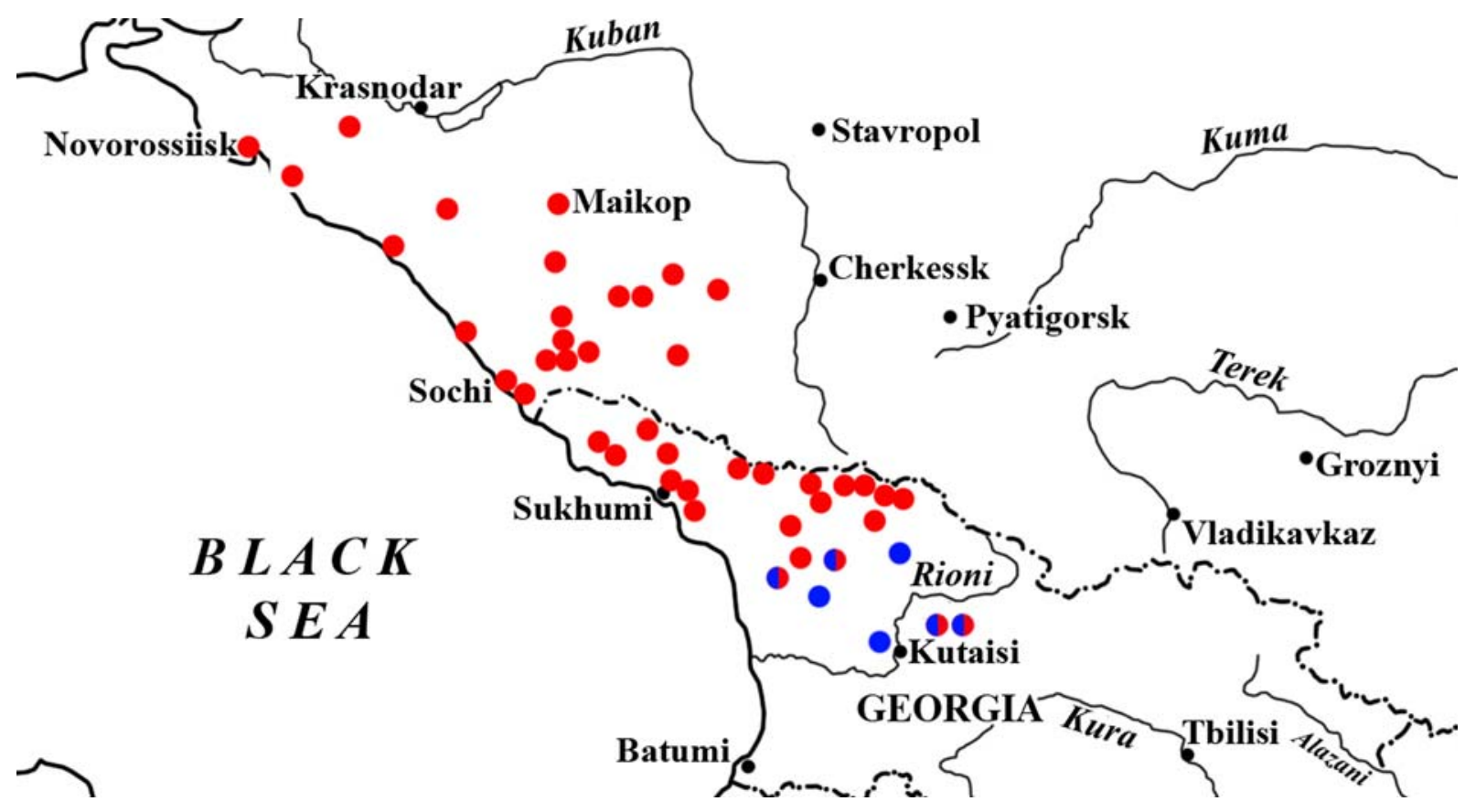

Map. Distribution of P. krivolutskyi Golovatch, 1977: red circles — morph A; red-and-blue circles — morph B; blue circles — morph C. Карта. Распространение P. krivolutskyi Golovatch, 1977: красные круги - морфа А; красно-синие круги — морфа В; синие круги морфа C. 


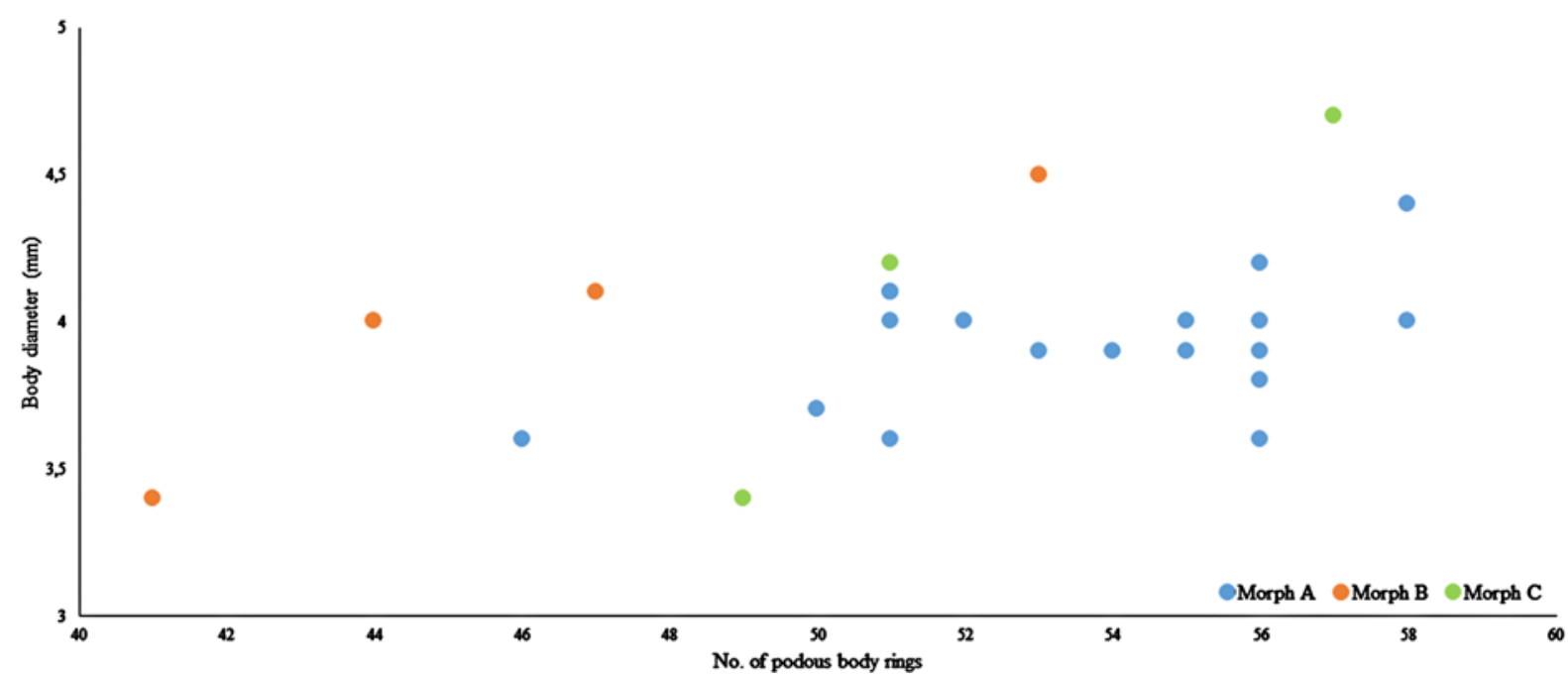

Fig. 25. Relationship between the number of podous body rings and body diameter in $\sigma^{7} \sigma^{7}$ of $P$. krivolutskyi. Рис. 25. Взаимосвязь между количеством сегментов и диаметром тела у Оำ $\sigma^{7}$. krivolutskyi.

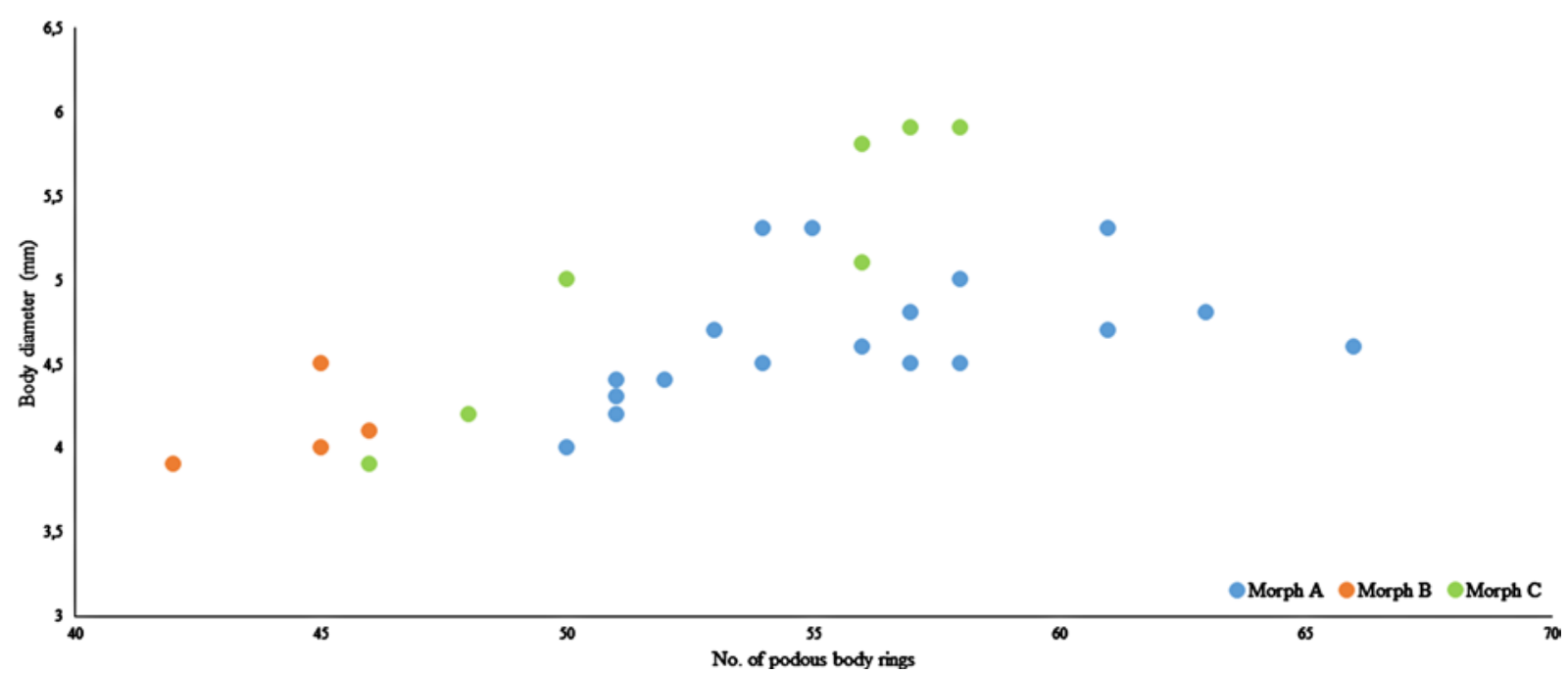

Fig. 26. Relationship between the number of podous body rings and body diameter in 우 of $P$. krivolutskyi. Рис. 26. Взаимосвязь между количеством сегментов и диаметром тела у +9 P. krivolutskyi.

morph $\mathrm{A}$ and is intermediate in coloration between morphs A and C. Morph C is found only in the southern part of the distribution area. There seems to be a rather gradual north-to-south succession from morph A, through morph B, to morph C (Map).

The $O^{7} O^{7}$ of $P$. krivolutskyi show certain morphological differences in gonopod structure as well. Usually the promere in morph A has two distinct distal lobes, $\mathbf{I}$ and $\mathbf{m}$ (Fig. 18), whereas that in morph $\mathrm{C}$ varies from having two similarly strong distal lobes, $\mathbf{I}$ and $\mathbf{~ m}$ [Golovatch, 1977], up to only a small lateral lobe (I), a vestigial mesal lobe and an apical seta (Figs 20-21). The mesomere in morph A is more usually rounded at the apex (Fig. 19), versus typically subacuminate in morph C (Fig. 21). The pseudoflagella of morph A are normally a little lower than to subequal in height to both pro- and mesomere or to the mesomere alone (Fig 19), whereas in morph $\mathrm{C}$ the pseudoflagella tend to be longer, higher than to about as high as the mesomere (Golovatch [1977] and Fig. 21).

Based on all available information, however, there seems to be no evident correlation between body colour patterns (= morphs) and gonopod conformation. Variations in gonopod characters seem to be rather random, likely individual, at most micropopulational.

Measurements reveal no significant differences between the morphs either. Graphs of the relationship between the number of podous body rings and body diameter (Figs 25-26) show that individuals of both sexes of morph B have fewer body rings, but no differences in body diameter. Box-plots of the ratio of body length to diameter (Fig. 27) likewise demonstrate that 


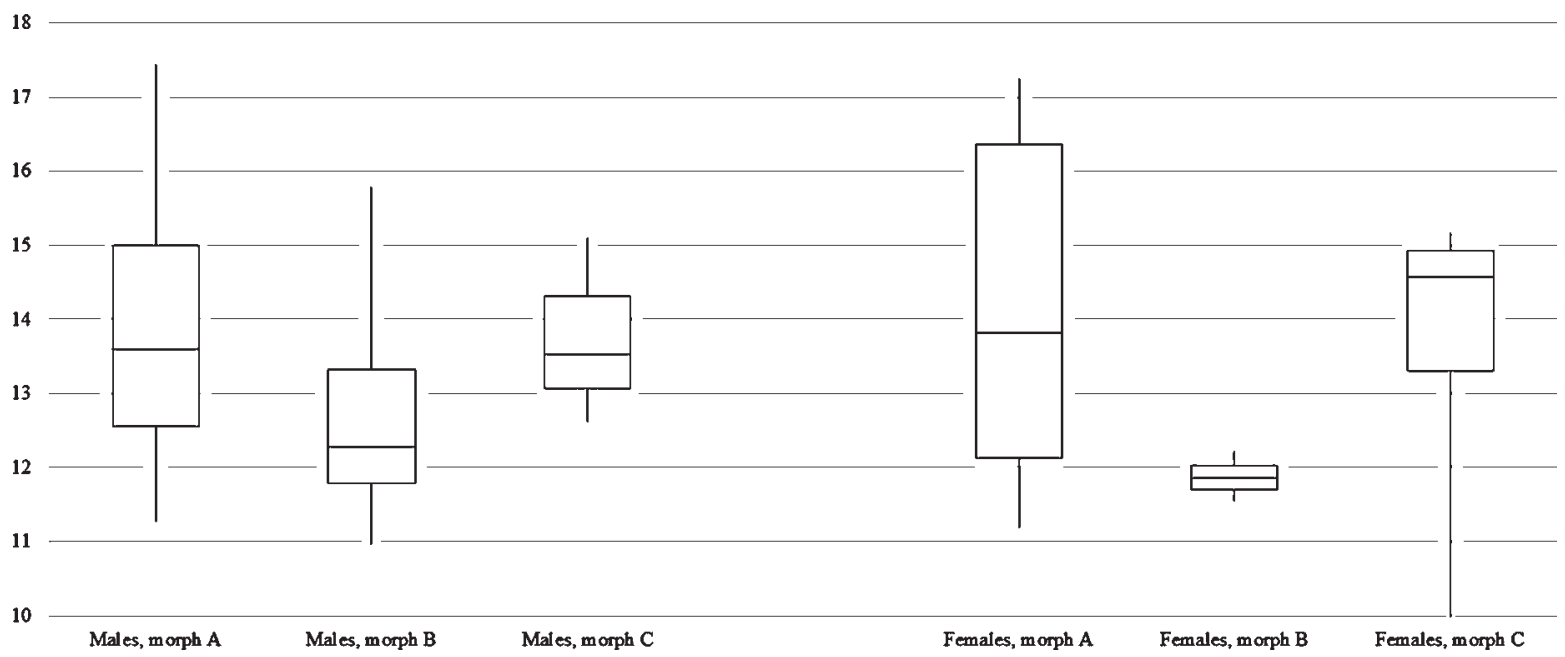

Fig. 27. Box-plots of the ratio of body length to diameter in $P$. krivolutskyi (max, min, quartiles $1 \& 3$, median).

Рис. 27. Коробчатые диаграммы соотношения длины тела и диаметра у P. krivolutskyi (максимум, минимум, квартили 1 и 3 , медиана).

adults of morph $B$ tend to be smaller in size than those of each other morph.

Molecular data, bar-coding in particular, would be most helpful in further refining the picture, but at the moment such information is unavailable.

ACKNOWLEDGEMENTS. I am grateful to all relevant collectors whose material was used in the present paper. I am especially deeply obliged to Sergei Golovatch, Moscow, Russia, who helped me in preparing and publishing this note. Special thanks go to Kirill Mikhailov and Elena Kudryavtseva (both ZMUM) who helped me incorporate the ZMUM samples into the collection.

\section{References}

Attems C. 1907. Myriopoden aus der Krim und dem Kaukasus // Arkiv för Zoologi. Bd.3. No.25. S.1-18.

Attems C. 1940. Beiträge zur Kenntnis der Iuliden // Annalen des Naturhistorischen Museums Wien. Bd.50. S.194-327.

Chumachenko Y.A. 2012. [Species diversity and seasonal activity of millipedes (Diplopoda) in a Taxus and Buxus grove of the Caucasian Nature Reserve] // Shoba S.A. (Ed.), Materials of the Lectures Presented at the 6th Congress of the V.V. Dokuchaev Soil Science Society. All-Russia conference with international participation, Petrozavodsk, 13-18 August 2012: "Soils of Russia: Present Condition, Prospects of Study and Use". A School for Young Researchers. Vol.2. P.451-452 [508 pp., in Russian].

Chumachenko Y.A. 2016. [Millipede (Diplopoda) populations in a yew-boxwood grove of the Caucasian Nature Reserve, Russia] // Zoologicheskii zhurnal. Vol.95. No.4. P.406-416 [in Russian, English summary].

Enghoff H. 1987. A new Olympic record: Pachyiulus hungaricus (Karsch) (Diplopoda: Juluda: Juludae) // The Entomologist's Monthly Magazine. Vol.123. P.208.

Frederiksen S., Petersen G., Enghoff H. 2012. How many species are there of Pachyiulus? A contribution to the taxonomy of Europe's largest millipedes (Diplopoda: Julida: Julidae) // Journal of Natural History. Vol.46. Nos 9-10. P.599-611.

Golovatch S.I. 1977. [New or poorly known Julida (Diplopoda) millipedes from the Sataplia State Nature Reserve (SSR Georgia)] // Byulleten' Moskovskogo obshchestva ispytatelei priro- dy. otdel biologicheskii. T.82. No.4. P.46-51 [in Russian, English summary].

Isaev V.M. 1911. [Observations of millipedes Diplopoda on the Black Sea coast of the Caucasus] // Trudy Imperatorskogo Sankt-Peterburgskogo obshchestva estestvoispytateley. Vol.42. No.1. P.292-310 [in Russian].

Kobakhidze D.N. 1965. [A list of millipedes (Diplopoda) of SSR Georgia] // Fragmenta Faunistica. Vol.11 (21). P.390-398 [in Russian, summaries in Polish and German].

Korobushkin D.I., Semenyuk I.I., Tuf I.H. 2016. An annotated checklist of the Chilopoda and Diplopoda (Myriapoda) of the Abrau Peninsula, northwestern Caucasus, Russia // Biodiversity Data Journal. Vol.4. P.1-33, e7308.

Lang J. 1959. [To the knowledge of millipedes (Diplopoda) of the USSR territory] // Zoologicheskii zhurnal. Vol.38. No.12. P.1790-1796 [in Russian, English summary].

Lignau N. 1903. Die Myriopoden am kaukasischen Schwarzmeerufer // Zapiski Imperatorskogo Novorossiyskogo obshchestva estestvoispytateley (Mémoires de la Société Impériale des Naturalistes de la Nouvelle-Russie), Odessa. T.25. No.1. P.82-149 [in German and Russian].

Lignau N. 1911. Neue Beiträge zur Myriopodenfauna des Kaukasus // Ezhegodnik Zoologicheskogo muzeya Imperatorskoy akademii nauk (Annuaire du Musée Zoologique de l'Académie Impériale des Sciences), St.-Pétersbourg. T.16. P.37-59.

Lignau N. 1915. Vielfüssler aus Abchasien // Ezhegodnik Zoologicheskogo muzeya Imperatorskoy akademii nauk (Annuaire du Musée Zoologique de 1'Académie Impériale des Sciences), Petrograd. T.19. P.349-401 (for 1914).

Lignau N.G. 1905. [Myriapoda of the Crimea] // Zapiski Imperatorskogo Novorossiyskogo obshchestva estestvoispytateley (Mémoires de la Société Impériale des Naturalistes de la NouvelleRussie), Odessa. T.28. P.197-199 [in Russian].

Lohmander H. 1936. Über die Diplopoden des Kaukasusgebietes // Göteborgs Kungliga Vetenskaps- och Vitterhets-Samhälles Handlingar. Ser. 5B. Bd.5. No.1. S.1-196.

Lokšina I.E., Golovatch S.I. 1979. Diplopoda of the USSR fauna // Pedobiologia. Vol.19. P.381-389.

Mauriès J.-P., Golovatch S.I., Stoev P. 1997. The millipedes of Albania: recent data, new taxa; systematical, nomenclatural and faunistical review (Myriapoda, Diplopoda) // Zoosystema. Vol.19. Nos 2-3. P.255-292.

Muralewicz W.S. 1907. Zur Myriapodenfauna des Kaukasus // Zoologischer Anzeiger. Bd. 31. H.11/12. S. 329-351.

Muralewicz W.S. 1911. [Essay on the fauna of Myriopoda of the Caucasus] // Izvestiya Kavkazskogo muzeya (Mitteilungen des 
Kaukasischen Museums). Bd.5. S.1- 80 [in Russian].

Muralewicz W.S. 1913. [Arthropods.-Arthropoda. Chapter VII. Class of myriapods.-Myriapoda] // Trudy obshchestva izucheniya Chernomorskogo poberezhya. T.2. P.215-221 [in Russian].

Striganova B.R. 1969a. [An assimilability evaluation of different leaf litter species by millipedes (Diplopoda)] // Zoologicheskii zhurnal. Vol.48. No.6. P.821-826 [in Russian, English summary] Striganova B.R. 1969b. [Distribution of millipedes (Diplopoda) in mixed forests of the northern Caucasus and their role in the decomposition of forest litter] // Zoologicheskii zhurnal. Vol.48. No.11. P.1623-1628 [in Russian, English summary].

Striganova B.R., Mazantseva G.P. 1979. Age and size structure of a population of Pachyiulus foetidissimus (Diplopoda) in the Caucasus // Oikos. Vol.32. P.416-421.

Talikadze D.A. 1984. [On the millipede fauna (Diplopoda) of the Colchidan Province of the Caucasus] // Zoologicheskii zhurnal. Vol.63. No.1. P.142-145 [in Russian, English summary]. 